\title{
The pacifist Jesus and the violent Jesus in the Gospel of Matthew
}

\begin{abstract}
Author:
David C. Sim ${ }^{1,2}$

Affiliations:

${ }^{1}$ School of Theology,

Australian Catholic

University, Australia

${ }^{2}$ Faculty of Theology, University of Pretoria, South Africa

Note:

Prof. Dr David C. Sim is participating as a research associate of Prof. Dr Andries G. van Aarde, Honorary Professor at the Faculty of Theology of the University of Pretoria, South Africa.

Correspondence to: David Sim

email:

david.sim@acu.edu.au

Postal address:

School of Theology, Australian Catholic University, Locked Bag 4115, Fitzroy, Victoria 3065, Australia

Dates:

Received: 27 May 2010 Accepted: 28 May 2010 Published: 07 June 2011

How to cite this article: Sim, D.C., 2011, 'The pacifist Jesus and the violent Jesus in the Gospel of Matthew', HTS Teologiese Studies/ Theological Studies 67(1) Art. \#860, 6 pages. DOI: 10.4102/hts.v67i1.860
\end{abstract}

(c) 2011. The Authors. Licensee: OpenJournals Publishing. This work is licensed under the Creative Commons Attribution License.
The Gospel of Matthew presents two starkly different depictions of Jesus. The earthly Jesus of the past is a pacifist who teaches non-violence, compassion, non-retaliation, forgiveness and love of enemies, and he lives his life according to these ideals. The other Jesus is the eschatological figure of judgement who is the antithesis of the earthly Jesus. This Jesus is violent, merciless and vengeful in his treatment of the wicked. The evangelist constructed and promoted this terrible figure of judgement to assist his readers to cope with certain situations of crisis, but in doing so he paid a steep christological price by presenting Jesus in contradictory terms.

\section{Introduction}

I wish to begin this study by making a statement that may surprise some readers. The Gospel of Matthew presents two very different portrayals of Jesus. In one of these, he is a pacifist who teaches peace, mercy, compassion, forgiveness, non-retaliation and love of enemies, and lives his life according to these principles. In the other he is a warrior figure, who leads an invincible army and who is determined to exact violent and merciless vengeance on his enemies. From the perspective of Matthew, the pacifist Jesus is the earthly or historical Jesus of the past who conducted a mission of teaching and healing in Galilee and who willingly died on a cross in Jerusalem, while the violent Jesus is the future or eschatological Jesus, who will return from heaven at the end of the age in order to instigate the final and universal judgement and deliver its attendant horrific punishments. These two depictions of Jesus, one in the past and the other in the future, could not be more different, and their presence in the same Gospel requires some explanation. Why does Matthew present the Jesus of the past in one way and then depict his future activity in such a conflicting or even a contradictory way?

It is the purpose of this study to answer this question. First of all, it will establish the different portrayals of Jesus in the Gospel, beginning with Matthew's depiction of the earthly Jesus and then describing his presentation as the eschatological figure of judgement. Then, having spelt out these very different accounts of Jesus, an explanation will be offered as to why Matthew viewed Jesus in such a contradictory way. It will be argued that, in terms of his presentation of the earthly or historical Jesus, Matthew was constrained to a large extent by the tradition he inherited. The Jesus of Christian memory was characterised by meekness, pacifism, compassion, love and non-retaliation, and Matthew follows his sources by representing Jesus in these very terms. However, since the Christian tradition was less consistent and more malleable in terms of the future role of Jesus, the evangelist had more freedom to construct his own vision of the eschatological Jesus. Matthew took full advantage of this situation to create a 'fantasy figure' who was violent, vengeful and merciless. The reason the evangelist creates this vindictive and brutal eschatological Jesus can be explained in sociological terms. Matthew's community was undergoing conflict and persecution and such an interpretation of the eschatological Jesus was necessary to assist his community in coping with their dire circumstances.

\section{The pacifist earthly Jesus}

Many of the ethical teachings of the Matthean Jesus are found in the Sermon on the Mount in Chapters 5-7. We shall focus on those that directly concern the topic of pacifism and nonretaliation. In the Beatitudes of Matthew 5:3-12, we find that Jesus blesses the meek, the merciful and the peacemakers. The Antitheses that follow in 5:21-48 provide practical examples of what Jesus' disciples are to do in concrete circumstances. They are not merely to refrain from killing, but are to resist the temptation to become angry (vv. 21-22). They are to reconcile themselves with their accusers (vv. 23-26) and not resist those who are evil (vv. 39-42). When struck on one cheek, they are to offer the other; when sued for one garment, they are to offer another garment as well; and when forced to go one mile, they are freely to go a second one. Jesus demands that 
his followers must love their enemies and pray for those who persecute them as they strive for perfection (vv. 43-48). In the Lord's Prayer in 6:9-13, Jesus teaches that Christians must forgive their debtors just as they are forgiven by God and this is reiterated in the following two verses (vv. 14-15). Then in 7:12 Jesus provides a summary of the Law in the Golden Rule: 'so whatever you wish that people would do to you, do so to them, for this is the Law and the prophets'. These key elements in the Sermon are repeated and reinforced later in the narrative.

The focus on love is emphasised in 22:34-40. Here Jesus is asked about the greatest commandment in the Law and responds by saying that the first and great commandment is the complete love of God. Then he adds that a second is just as important, that people should love their neighbour as themselves (cf. Lv 19:18). The love of neighbour also features in 19:16-22, where Jesus explains the more important commandments and highlights this one in particular. Scholars agree that the Golden Rule in 7:12 (treating others as you would be treated by them) and the demand to love one's neighbour as oneself amount to much the same thing. The notion of forgiveness is prominent in Chapter 18. In verses 21-22, Jesus tells Peter that he should be prepared to forgive not just on seven occasions, but seventy times seven. This tradition provides the setting for a parable about the necessity of forgiveness and mercy in 18:23-35. A little later in 23:23, Jesus defines the weightier parts of the Law as justice, mercy and faith (or faithfulness). The demands of following Jesus are spelt out in a very practical way in the so-called parable of the sheep and goats in 25:31-46, which is in reality a tradition about the final judgement. The criteria for the judgement are listed as providing food to the hungry, providing drink to the thirsty, welcoming the stranger, clothing the naked, and visiting the sick and those in prison.

The evangelist takes care to emphasise that Jesus practises what he preaches (Bauer 1988:60-63; Riches 2000:284; Allison 2005:149-153). He too is meek $(11: 29 ; 21: 5)$ and his mission is characterised by an emphasis on mercy. Jesus shows mercy by eating with tax collectors and sinners (9:9-13), but it is in his healings and exorcisms that his compassion is most clearly illustrated. In the healing of the two blind men in 9:27-31, the afflicted men approach Jesus and ask him to have mercy on them. Jesus responds with compassion by healing them. A second healing of two blind men in 20:29-34 follows the same pattern. In response to their double plea for Jesus to show mercy to them, Jesus takes pity on them and opens their eyes. The Canaanite woman also appeals to Jesus' mercy to heal her possessed daughter, and Jesus (eventually) accedes to her request (15:21-28). In a similar episode, a father asks Jesus to have mercy on his possessed son, and Jesus exorcises the unclean spirit (17:14-21). The same theme appears in the healings that Jesus performs on the Sabbath in $12: 1-14$. When he is criticised by the Pharisees, Jesus cites, in his defence, Hosea 6:6; 'I desire mercy and not sacrifice' (cf. 9:13). Jesus' constant demonstration of mercy in Matthew's Gospel is perfectly consistent with the tradition in 23:23 that mercy is one of the fundamental aspects of the Law.
It is of course in the passion narrative where Jesus best illustrates the qualities of meekness, non-retaliation and nonviolence. As he is arrested, Jesus does not resist. When one of his followers retaliates by cutting off the ear of the high priest's slave, Jesus denounces this violent act by stating that all who take the sword will perish by the sword (26:51-52). During his trial before the High Priest and the council, Jesus remains meek and largely silent. He offers no resistance when he is spat upon and beaten (26:57-68) and he continues to adopt his silent and non-retaliatory posture before Pilate (27:11-26). Jesus is then handed to his executioners who mock him, spit on him, beat him and humiliate him (27:2731). Again, Jesus maintains a dignified silence and offers no resistance to these evil Roman soldiers. As he hangs on the cross, he is subjected to a range of derisory comments by passersby, the chief priests, scribes and elders and even by those who were crucified with him (27:39-44). Once more Jesus makes no attempt to respond and his final sound is a loud cry as he dies (27:50). Matthew therefore depicts Jesus as the perfect Christian role model. Despite being subjected to a host of indignities and brutal punishments, Jesus offers no resistance to his enemies. He does not get angry, but remains meek, passive and silent as he fulfills the will of God.

Much of Matthew's depiction of the teaching and example of the earthly pacifistic Jesus traces back to his Christian source material. He follows quite closely those aspects of the Marcan passion narrative, which portray Jesus as physically unresisting and verbally passive. Mark, too, knows the command to love one's neighbour (12:2834) and he also portrays the miracles of Jesus as acts of compassion and mercy (cf. 10:46-52), though it is true that Matthew emphasises this motif much more than his source. Similarly, much of the didactic material where Jesus teaches conciliation, forgiveness and non-retaliation stems from $\mathrm{Q}$ (cf. Lk 6:12, 27-31, 35-36; 12:57-59; 17:4). These traditions about the character of Jesus and his fundamental teachings are represented in other New Testament writings. Paul refers to the meekness and gentleness of Jesus (2 Cor 10:1), his compassion (Phlp 1:8) and humility (Phlp 2:5-11; cf. 2 Cor 8:9), and the emphasis on love (cf. Rm 13:8-10; Gl 5:13-14; cf. 1 Cor 13:1-14:1). Like Matthew and other early Christians, Paul looked upon Jesus as the definitive role model whose example was to be emulated (1 Cor 11:1; cf. Rm 15:1-7). The first epistle of Peter also provides a clear statement of this tradition. Jesus provided an example that should be followed: he committed no sin, committed no acts of guile, did not revile those who reviled him and who did not threaten when he suffered (1 Pt 2:21-23).

It is clear from the above that Matthew inherited a common Christian narrative that emphasised the meekness and mercy of Jesus and his pacifistic response to violence. The example set by Jesus was to be imitated by those who followed him. The evangelist took over this tradition and highlighted even more some aspects of it. Having established the nature and character of the earthly Jesus in Matthew's Gospel, we may turn to his depiction of the eschatological Jesus. 


\section{The violent eschatological Jesus}

Matthew also inherited a common Christian tradition that the risen Christ would return from heaven and that this event would initiate the universal and final judgement. But while most other Christian texts do not emphasise these endtime events and are rather vague about their precise details, Matthew both focuses intensely upon them and provides a colourful description of them. Much of his portrayal is redactional (Sim 1996:93-147). It is important to note how the evangelist describes the return of Jesus, because it is quite unexpected in the context of his presentation of the earthly Jesus. The clearest depiction of this event is found in Matthew 24:29-31. In this redactional text, Matthew describes the returning Jesus in overtly military terms (Sim 1996:100-108). He comes on the clouds of heaven with power and glory, with a military standard and a trumpet call, accompanied by an angelic army (cf. the reference to legions of angels in 26:53). This is a far cry from the pacifist earthly Jesus who appears in the rest of the Gospel. Jesus is no longer meek and mild, but the leader of an army of angels whose primary task is to oversee the universal judgement (25:31-46; cf. 7:24-27) and execute divine justice. The evangelist spells out the fate of the righteous in a number of pericopes (Sim 1996:140-145). They will be transformed into angels (22:30; cf. 13:43) and be given eternal life $(19: 16 ; 19: 29 ; 25: 46)$. The righteous will also participate in the messianic banquet (8:11-12), a very common Jewish eschatological theme and will live in peace and harmony in the presence of God $(5: 8 ; 18: 10)$.

It is, however, the opposite notion - the fate of the wicked - that is of more concern to Matthew and his views are the harshest that we find in the New Testament (Sim 1996:129140). Matthew can at times speak of their fate in very general non-descript terms. They will meet with condemnation (12:41-42), destruction (7:13) and eternal punishment (25:46), but he also provides specific details. The wicked will be sent to a place of complete darkness. In three redactional sections, the evangelist states that they will be consigned to the outer darkness (8:12; 22:13 and 25:30), a result of their removal from the presence and the light of God. The main theme, however, is that the wicked will burn for eternity and many of the evangelist's references to this topic are the result of his editorial activity.

The Matthean Jesus identifies the place of fiery punishment as Gehenna (cf. 4 Ezr 7:36; Sib. Or. 4:186). When referring to this terrible place, he most often simply refers to Gehenna $(5: 29-30 ; 10: 28 ; 23: 15,33)$ or its Greek equivalent Hades (11:23; 16:18), though at times he uses the more descriptive 'Gehenna of fire' (5:22; 18:9). On other occasions he speaks of the wicked being cast into the eternal fire $(3: 7-12 ; 7: 19 ; 18: 8$; $25: 41)$ or the furnace of fire $(13: 42,50)$. When we tally all the Matthean texts that refer to the theme that after the final judgement the wicked will be punished by burning forever in the fires of Gehenna the evidence is impressive. It is even more so once we consider that most of these references are redactional, either inserted by the evangelist into his sources or created outright by him. While this was a very common theme in Jewish eschatological circles (Sim 1996:47-48), it is not so prominent in the Christian texts of the New Testament (Sim 1996:130-134), though it is found in the book of Revelation ( $\operatorname{Rv} 19: 20 ; 20: 10,14-15)$.

But Matthew says even more than this about the end-time punishment of the wicked. He emphasises that the fate of the wicked will involve torment and torture. The story of the Gadarene demoniacs in Matthew 8:28-34 is relevant here. In this story, a number of demons ask Jesus if he has come to torture them $[\beta \alpha \sigma \alpha v i \zeta \omega]$ before the time (or before the judgement). These supernatural figures understand what awaits them (cf. 25:41), and they ask Jesus if their torment is to begin before the judgement. While it is true that the torture to which they refer might simply be the burning by eternal fire, there may be more to this motif than that. A common theme in Jewish eschatological circles was that the wicked, in addition to being burned eternally, would also be tortured by angelic tormenters (cf. Sir 39:28-31; 2 En. 10; T.Ab. 12:1-2; T. Levi 3:2). Matthew, too, seems to reflect this theme (Sim 1999:707-715). In the parable of the unforgiving servant in Matthew 18:23-35, a servant who was forgiven a large debt by his master failed to show similar mercy to those who owed him money. When his master learned of this, he delivered the servant to the torturers [oi $\beta \alpha \sigma \alpha v i \sigma \tau \alpha i]$. The parable ends with the message that God will do likewise at the judgement. These torturers can be identified with the angelic tormenters of the wicked. The same motif probably underlies the strange parable of the wicked servant who is dissected at the eschaton (Sim 2002a).

Matthew's intense focus on the eschatological plight of the wicked is further evidenced in the delight he appears to take in their reaction to their punishment. He says on no less than six occasions, five of which are redactional, that the wicked will weep in misery and gnash their teeth in rage as they realise the terrible nature of their eternal fate $(8: 12 ; 13: 42$, $13: 50 ; 22: 13 ; 24: 51 ; 25: 30)$.

We are now in a position to compare Matthew's earthly Jesus with his eschatological Jesus. Whereas the Jesus of the past was characterised by non-violence, non-retaliation, mercy and forgiveness, the future Jesus has none of these qualities. He will be a military commander at the head of his angelic army and in this capacity he will subject the wicked to considerable violence after they have been judged unworthy at the final judgement. They will be placed well away from the light of the divine realm into Gehenna, where they will certainly be punished by eternal fire and probably punished by angelic torturers as well. In this end-time scenario, there is no emphasis on peacemaking; there is warfare between the forces of righteousness and their evil counterparts. There is no room for meekness, pacifism, non-retaliation and turning the other cheek here as the heavenly Christ seeks vengeance against his enemies in a particularly violent fashion with an emphasis on pain and torture. The concepts of forgiveness and mercy, so integral to Matthew's portrayal of the earthly Jesus, have given way to the concepts of payback and vindictiveness. The wicked are given no opportunity to 
repent, either at the judgement or later. Their punishment is eternal, which precludes any future acts of mercy or forgiveness on the part of Jesus (and God). This gruesome and disturbing aspect of Matthew's Gospel, which a number of recent studies have highlighted (Reid 2004; Carter 2005; Neville 2007), requires explanation. Why did the evangelist transform the pacifist and merciful historical Jesus into this violent and vengeful eschatological fantasy figure?

\section{The social setting of Matthew's community}

It is well recognised that ancient Jewish and Christian groups who resorted to a brutal and vengeful eschatological scenario did so in response to a situation of great crisis, usually but not always persecution, that led to an intense sense of alienation from the wider world (Sim 1996:54-62). The belief that the wicked would be punished by horrible and torturous means served to console the oppressed group that their enemies will face punishment and to restore their confidence in the justice of God (Sim 1996:67-68). Matthew's terrible eschatological schema can be explained in a similar fashion.

I have examined the Gospel's complex social setting in the decades following the Jewish revolt of 66-70 CE in a number of previous studies (Sim 1996:181-221, 1998:109-256) and all that is necessary here is a summary of those discussions. First and foremost, it is generally agreed that the Matthean community came into conflict with Formative Judaism, a coalition of forces led by the Pharisees and their scribal associates (Overman 1990; Saldarini 1994; Repschinski 2000). These groups in particular emerge as the real villains of Matthew's story. They are offended by the teaching of Jesus (15:12), they think evil of him (9:4), they charge him with blasphemy (9:3) and demon-possession (9:34; 12:24), they attack him for disregarding the Torah (12:2; cf. 15:1-2) and for eating with sinners (9:11), they test him (19:3; 22:15-16, 34-35) and they plot to kill him (12:14).

The Matthean Jesus responds in kind to these opponents and unleashes a series of stinging verbal attacks on them which culminates in the discourse against the scribes and Pharisees in Chapter 23. They are hypocrites $(15: 7 ; 22: 18 ; 23: 13,15,23$, 25, 27-29; cf. 6:2, 5, 16; 23:3), blind men (15:14; 23:16, 17, 19, $24,26)$, children of Gehenna (23:15) and a brood of vipers $(3: 7 ; 12: 34 ; 23: 33)$. Furthermore, they fail to practise what they preach $(23: 3,27-29)$, they place intolerable burdens on others (23:4), they solicit admiration (23:5-7), they place their own tradition before the will of God (15:2-3; 23:15-26), they lack the appropriate level of righteousness (5:20) and they are even guilty of murder (23:29-36; cf. 22:6). In abusing their leadership roles, they lead the people astray (15:14), prevent them from entering the kingdom of heaven (23:13) and so make their followers twice as much a child of Gehenna as they are (23:15). The scribes and Pharisees are described as evil [ாоипро́ร์; 9:4; 12:34; 22:18), which identifies them as followers of Satan, 'the evil one' ([o movnpós ; 5:37; 6:13; 13:19, 38) (Sim 1996:76-77).
There is a consensus that this conflict between Jesus and the scribes and Pharisees in the Gospel story reflects a very bitter dispute between the evangelist's Christian Jewish community and the proponents of Formative Judaism. This debate centred on the status of Jesus. While the Matthean community accepted that Jesus was the Messiah, Son of God and so on who fulfilled the Jewish scriptures, their opponents marked him as a deceiver and a servant of Satan (cf. 9:34; 12:22-32; cf. 27:62-66; 28:11-15). A further and related aspect was the correct interpretation of the Torah. Matthew's group followed the interpretation of Jesus (5:21-48; 7:12; 12:1-14; 15:1-20; 22:34-40; 23:23), while the scribes and Pharisees upheld the tradition of the elders $(15: 2,6)$. The Gospel testifies that this dispute did not remain at the academic level; the evangelist's smaller and weaker community was persecuted by its more powerful enemies (Sim 1996:192-198) and this is reflected in the evangelist's polemical response.

The Law-observant Matthean community was also engaged in an ideological struggle with those elements in the Christian tradition that failed to keep the ritual demands of the Torah, notably the Pauline tradition (Sim 1998:188-211, 2002b, 2007, 2008). There are two key texts in this regard. In 7:15-23, Jesus presides over the final judgement, and condemns those who acknowledge him as Lord because they are workers of lawlessness ['avouía]. The condemned are clearly Christians who acknowledge the Lordship of Jesus but they are cast from his presence because they do not observe the Torah as Jesus himself had commanded in 5:17-19 (Sim 2007). The other passage is 13:36-43, the interpretation of the parable of the tares. In this text the angels of the Son of Man will gather out of his kingdom (the church) those who are guilty of 'ovouía and cast them into the fiery furnace (Sim 1996:210 213).

A further aspect of Matthew's social setting is its Roman Imperial context (Carter 2001). Matthew's story of Jesus is dominated by the reality of Roman rule. Jesus lived under Roman occupation and was executed by Roman soldiers on the order of the local Roman governor. The evangelist, too, lived in a world completely dominated by the military and economic power of Rome (Carter 2001:9-53) and it is clear that he opposed absolutely Roman arrogance, power and exploitation, as well as its idolatrous Imperial theology. From Matthew's perspective, the Roman Empire was in league with Satan and as such stood totally opposed to the purposes of God. This is made clear in the temptation narrative (4:111), where Satan offers Jesus all the kingdoms of the world (vv. 8-9) if he will reject God and worship Satan instead. The implication here is that Satan controls all the worldly powers, including Rome, the most dominant power in Matthew's setting (Carter 2001:62-63).

There is no evidence that the members of Matthew's community had been actively persecuted by the Romans, but their dual affiliation with both the Jesus movement and the wider Jewish community, must have made them distrustful and fearful of this 'evil Empire'. As Christians, they would 
have been aware that Nero had singled out and persecuted the Christians of Rome (Sim 1996:206-207) and, as Jews, they would have experienced Roman antagonism on account of the Jewish rebellion.

Finally, there are some indications in the Gospel that the members of Matthew's group had experienced some persecution at the hands of their Gentile neighbours. The Gospel contains a number of anti-Gentile traditions (5:46-47; 6:7-8; 6:31-32; 7:6 and 18:15-17), which mark Gentiles as an outsider group that is not to be emulated and with which contact is to be kept to a minimum (Sim 1996:201-204). These texts are best explained by the hypothesis that the evangelist's community had suffered mistreatment by local Gentiles in the recent past. Many Jews, including Christian Jews, were persecuted by their Gentile neighbours during both the Jewish revolt and the period that followed the Roman victory, and Matthew's small church would have inevitably been caught up in these terrible events (Sim 1996:204-208). The Gospel was written when these acts of violence were still fresh in the memory and when renewed attacks were an ever-present possibility.

We can see, therefore, that the evangelist's group was to all intents and purposes in conflict with all outsider groups the non-Christian Jewish community, the Law-liberal wider Christian church, local Gentiles and even the Roman Empire. This complex situation led to a 'siege mentality' and a developed sense of isolation and alienation from the world at large (Sim 1996:218-219). These dire circumstances and the powerlessness to change them fostered an apocalyptic response that focused on the future, especially the rewards for the righteous who persevered and the horrible punishments for those who inflicted their suffering. In other words, Matthew constructs his vindictive and violent eschatological Jesus in order to help his community cope with its many crises and its growing sense of alienation.

But in constructing this brutal end-time figure Matthew pays a very heavy christological price. The future Jesus he describes exhibits almost none of the characteristics of the earthly Jesus of the past. There is no meekness or humility, no turning the other cheek, no warnings against the use of violence, no love of enemies or prayers for persecutors and no mercy and forgiveness. Rather, the Son of Man who comes in judgement arrives in glory to retaliate and exact vengeance in a merciless and extremely violent manner. He is, in a very real sense, the antithesis of the Matthean Jesus at the time of his ministry.

\section{Conclusions}

This study has argued that the Gospel of Matthew contains two very different, even contradictory, presentations of Jesus. The Jesus of the past, the central figure in Matthew's story, is characterised by a pacifistic nature and perspective. He preaches a gospel of peace, non-violence, non-retaliation, love, mercy, and forgiveness, and he is himself a perfect role model in this respect. But Matthew refers to another Jesus, the eschatological Jesus who will return at the end of the age to oversee the final judgement. The character of this Jesus is not loving and gentle but brutal and vengeful and one of his major roles is to punish his enemies, both the supernatural and the human, in a thoroughly violent fashion. This Jesus will consign the wicked for all eternity to the fires of Gehenna with accompanying angelic tormenters. These two figures are indeed the same person and yet they share almost nothing in common. One can only wonder how the evangelist and his readers could accept such contradictory portrayals of Jesus in the same text.

We can, of course, explain why Matthew envisaged the returning Jesus in these violent terms when most Christians of the first century did not do so. Such a brutal and vengeful figure was necessary to help the evangelist's embattled and alienated community cope with a number of critical circumstances, but it is clear that in taking this particular option Matthew paid a steep christological price. The militaristic, violent, vengeful, unforgiving and unmerciful Jesus who returns in glory at the end of the age is the complete antithesis of all that the earthly Jesus represented, and seems to break all the ethical rules that the earlier Jesus established (Carter 2005:102; Neville 2007:153). While this situation presumably posed no problem for Matthew or his community, who either ignored or somehow resolved the contradiction, it can and should disturb Christians in the modern day. Christians today who wish to promote peace, non-retaliation, tolerance and understanding need to follow in the footsteps of Matthew's earthly Jesus, and to see his eschatological Jesus for what he is, a violent fantasy figure created to combat the critical situations that he and his readers were experiencing.

\section{Acknowledgement}

I am delighted to contribute to this Festschrift for Prof. Andries van Aarde. Andries has made a significant contribution to the general field of theology and New Testament studies in particular, in both South Africa and the international arena. I value his scholarship and his friendship.

\section{References}

Allison, D.C., 2005, Studies in Matthew: Interpretation past and present, Grand Rapids, Baker Academic.

Bauer, D.R., 1988, The structure of Matthew's Gospel: A study in literary design, Sheffield Academic Press, Sheffield.

Carter, W., 2001, Matthew and empire: Initial explorations, Trinity Press International, Harrisburg.

Carter, W., 2005, 'Constructions of violence and identities in Matthew's Gospel', in S. Matthew \& E.L. Gibson (eds.), Violence in the New Testament, pp. 81-108, T \& T Clark International, London.

Neville, D.J., 2007, 'Toward a teleology of peace: Contesting Matthew's violent eschatology', Journal for the Study of New Testament 30, 131-161. doi:10.1177/0142064X07084773

Overman, J.A., 1990, Matthew's Gospel and Formative Judaism: The social world of the Matthean community, Fortress Press, Minneapolis.

Reed, B., 2004, 'Violent endings in Matthew's parables and Christian nonviolence', Catholic Bibilical Quartely 66, 237-255.

Repschinski, B., 2000, The controversy stories in the gospel of Matthew: Their redaction, form and relevance for the relationship between the Matthean community and Formative Judaism, Göttingen, Vandenhoeck \& Ruprecht. (FRLANT 189). 
Riches, J., 2000, Conflicting mythologies: Identity formation in the gospels of Mark and Matthew, Edinburgh, T \& T Clark. (SNTW).

Saldarini, A.J., 1994, Matthew's Christian-Jewish Community, University of Chicago Press, Chicago.

Sim, D.C., 1996, Apocalyptic eschatology in the Gospel of Matthew, Cambridge University Press, Cambridge. (SNTSMS 88).

Sim, D.C., 1998, The Gospel of Matthew and Christian Judaism: The history and social setting of the Matthean community, Edinburgh, T \& T Clark. (SNTW).

Sim, D.C., 1999, 'Angels of eschatological punishment in the Jewish and Christian apocalyptic traditions, and in the gospel of Matthew' HTS Teologiese Studies/ apocalyptic traditions, and in the
Sim, D.C., 2002a, 'The dissection of the wicked servant in Matthew 24:51', HTS Teologiese Studies/Theological Studies 58, 172-184.

Sim, D.C., 2002b, 'Matthew's anti-Paulinism: A neglected feature of Matthean Studies', HTS Teolgiese Studies Theological Studies 58, 767-783.

Sim, D.C., 2007, 'Matthew 7:21-23: Further evidence of its anti-Pauline Perspective', New Testament Studies 53, 325-343. doi:10.1017/S0028688507000161

Sim, D.C., 2008, 'Matthew, Paul and the origin and nature of the gentile mission: The great commission in Matthew 28:16-20 as an anti-Pauline Tradition', HTS Teologiese Studies/Theological Studies 64, 377-392. 